\title{
INNOVATIONS AND BUSINESS ACTIVITIES OF SLOVAK START-UP ENTERPRISES
}

\author{
Ladislav Mura ${ }^{1}$ \\ DOI: https://doi.org/10.31410/LIMEN.S.P.2020.57
}

\begin{abstract}
An essential part of the corporate sector is formed by small and highly innovative enterprises, the start-ups. They introduce highly innovative activities, new solutions, integrate research results into their activities, as well as apply new technologies in their everyday practice. Start-ups are increasingly popular in different sectors of the national economy since they are a vital part of the entrepreneurial environment. The entrepreneurial activity of startups focuses on highly innovative products or services with high added value for the target customer. The main goal of the current paper is to target the innovative activity of Slovak startups. The paper presents partial results of the research conducted by targeting Slovak start-ups. The research results conclude that innovative start-ups are the driving force of the entrepreneurial sector. The innovative activities of these businesses rank them among the highly competitive and successful players on the market, even in a challenging business environment.
\end{abstract}

Keywords: Enterprises, Business activities, Innovations, Start-up.

\section{INTRODUCTION}

The market economy in every part of the world is established and subsequently shaped by business units. Businesses form a significant part of the economy by creating value, producing products, providing services, creating workplaces and development of regions where they conduct their activity. The business sector consists of several groups of companies. The largest group is formed by small enterprises. Companies with a high degree of innovation, flexibility and creativity, which we refer to as start-ups have an interesting position on the market. These types of business units are characterized by interesting and valuable ideas that can contribute to achieve success or turn the business activity prosperous. Start-ups are the key players of dynamic development all over the world as well as in the EU. Most of the startups operate in the service sector and provide their services offering new solutions improving our everyday life. Typically they are representing the sector of technologies, IT solutions, energetics, etc. They benefit from offering simple and flexible solutions to everyday problems.

The basis of any start-up business is a unique idea, which can be commercialized on the market. An entrepreneur with a good idea develops a business model, the viability of which is assessed. As start-ups focus to provide benefits by applying simple and new solutions, the viability of the business activity is presumed. Start-ups represent business strategies aimed at satisfying the new and future needs of potential customers. This should be mentioned as their unique feature compared to small businesses based on the classical model. Start-ups are based on unique and not presented ideas yet. These become significantly innovative and generate high demand on the market.

1 Pan-European University in Bratislava, Faculty of Economics and Business, Tematínska 10,85105 Bratislava, Slovak Republic 
It is essential to note that the basis for innovation and the establishment of start-ups is backed by the results of science, technology and development. It is difficult to imagine the existence of start-ups without this background. Therefore, the government and certain governmental bodies and further institutions should support the scientific-technological development and look for solutions that result in the desired effect important for the society. Although innovations are recognized as new ideas or solutions, their benefit goes beyond this definition. Innovation is also described as a change that contributes to the improvement of existing products or services, as well as there can come in form of organizational changes. Innovation can also be defined as an improved, enhanced quality of existing products or solutions.

\section{THEORETICAL BACKGROUND}

Although we speak about the small business sector, we should note that start-ups are business units with different features and character than the businesses in the SME sector. In terms of categorization, start-ups are small enterprises and belong to sub-group of micro-enterprises. Start-up is formed by 1-3 entrepreneurs, who come up with a brilliant idea or change supporting progress. Start-ups differ from the rest of enterprises by their life-cycle, business strategy or business model that enables them to enter, develop and maintain their activities on the target market.

The changing situation in the local and world market is significantly determined by the phenomenon of globalization. Globalization is strongly supporting the expansion of foreign direct investment, which means the investment is flowing beyond the borders, creating new business units, spreading innovation and expanding the existing business activities. This tendency results in the establishment of new forms of entrepreneurship, which need to be legally defined and recognized. The small and medium-sized enterprise sector in the majority of countries is also represented by start-ups. In the sector of larger companies, we are witnessing the expansion of a simple joint-stock company (Miloševičová and Trel'ová, 2018).

The challenging business conditions will shift a focus on sustainable entrepreneurship and the social responsibility of the business. Both on a domestic and international scale a changing business attitude can be detected, which in addition to internal priorities will also emphasize long-term sustainability. According to Agarwal et al (2018), this can be achieved by combining innovation and environmental policy. An integrated approach to the management of the business unit is established.

Although the business environment is very demanding in terms of competition and changing demands of customers, there remains a gap, where business motivation results in the establishment of new business units. However, only those businesses have a chance to succeed which are significantly different from the existing ones on the market. Differentiation offers an idea, improvement or satisfaction of need partially satisfied or not satisfied at all. This gap is filled by start-ups (Amorós, Cristi and Naudé, 2020). Motivated entrepreneurs will introduce products with high added value. This fact is approved by research conducted in 70 countries. Entrepreneurship contributes to satisfaction not only the customer but also the entrepreneur running the business.

The authors team of Estay, Durrieu and Akhter (2013) were interested to answer some important questions about the role of motivation in start-up enterprises. They wanted to know what is important to do when the business is started, how entrepreneurial motivation affects the start-up, and to what extent the project opportunities influence starting a new business. A 
questionnaire survey was prepared for those entrepreneurs who were motivated to start a new business. The most motivating factors to start a business were the following: enter the market with a new product, project opportunities - focus on calls, innovations as adventure for enterprise, innovation of existing products or finding completely new solutions. The representatives of innovative enterprises believe that this kind of entrepreneurial activity will result in tangible financial benefit and satisfaction of being a pioneer in innovation.

At this stage, it is necessary to approach start-ups as a form of entrepreneurship. Slávik et al (2020) emphasize that start-up is a very young form of enterprise, where we can detect different organizational and personnel structure than in the case of other types of enterprises. The startup is dominated by the founder building the network of business relationships. The author's team in their research found that age, qualification and reason to start a business as well as the quality of teamwork play an essential role. In the case of start-ups, it is about an intensive development of business with a special focus on innovation. They find it necessary to monitor the business ideas and the cycle of investments. According to authors, the founders of start-ups are better leaders than appointed managers, since the quality of leadership depends on the phase of the cycle the start-up is experiencing. Start-ups are struggling with limited opportunities and weaknesses associated with this type of business. However, the lack of experience is compensated with a high level of interest, enthusiasm, determination and hard work.

The context above shows that start-ups are an interesting and significant part of the business base in the economy. They are characterized by a high level of creativity, innovative ability, flexibility, opportunity to implement their ideas, effective work and implementation of their own business strategy. Mainly in younger market economies e.g. Slovakia, start-up initiatives play an essential role. They provide an opportunity to launch business ideas, develop entrepreneurial processes and launch new, innovative products on the market.

Bednar, Tariskova and Zagorsek (2018) consider start-ups to be rapidly developing business units and representatives of a modern business model. Generating ideas and investments are the core of this business model. The team of authors of this article is focusing to define the models used by Slovak start-ups. As a highly innovative businesses, start-ups can achieve not only success but can also generate a decent profit. According to the findings of the authors, there are different models present in Slovakia, where significant differences can be detected in prices, profit and economic indicators. Establishing a start-up is not automatically associated with success on the market.

Start-ups characterized by innovation represent significant potential for various changes in the industry sector and economic recovery. The scientific literature does not provide a detailed answer for the overall activities of start-ups. However, there are relatively systematic overviews about the existence of start-up businesses. Passaro, Quinto and Thomas (2020) warn the attention that the importance of these types of businesses will increase in relation to the restructuring of economies and the need to adapt to market changes. Chang, Kim, J.H, Kim, Y.S. (2020) add that costs, time and approaches can be the basic barriers for start-ups. Their results show that these barriers converge to reduced dispersion. This is later reflected in the regions they operate in.

Pitekova and Vrablikova (2019) focused their attention on examining the start-up initiatives concerning the regions of Slovakia. The regions characterized by the presence of innovative start-ups show a higher level of innovation and creativity, which leads to a higher standard of living. Human resources are a crucial aspect of start-ups. The ideas are generated by people, 
which is the basis of start-ups to operate. Thus, creative potential is concentrating in individual regions of Slovakia. The authors compared the regions of Slovakia based on the following factors: frequency of start-up initiatives, implementation of innovations, level of employment in innovative and developing businesses, technological equipment, micro and macro environment of the business. They came to conclusion that a significant determinant for the functioning of the start-up is consulting - the basis for creative output.

It is clearly demonstrated that innovative and start-up businesses providing added value play a significant position in the development of the regional economy. They create and added value both for the company itself and the region they operate in.

Innovations and creative solutions are the comparative advantages of start-ups compared to other types of businesses. Innovations do not often require technologies as expected, more important aspect is the creative and high-quality human resources with adequate skills and innovative ideas to be implemented on the market (Vnoučková, 2018). Leaders among startups are technology oriented businesses representing different sectors of the economy. The research of the author pointed to significant results detected between the factor of age and creativity as well as the factor of creativity and the history of business. The author also emphasizes that professional training and qualification, professional assistance and project orientation are essential for start-ups.

\section{AIM, MATERIAL AND METHODS}

This article is addressing an interesting field of entrepreneurship, mainly the sector of small and medium enterprises, which are characterized by a high degree of innovative activity. These businesses introduce new solutions on a large scale of the national economy. Thematically, the article is addressing the start-ups. The article will focus on certain aspects of these types of businesses. The main goal of the article is to present some of the important partial research results as a part of project VEGA 1/0813/19 - "Managing the development of innovative and start-up forms of businesses in international environment and verification of INMARK concept". As a partial goal is defined to present the activity of a specific group of business units, such as the start-up companies. In order to provide adequate information about start-ups, it was necessary to introduce the theoretical background of start-ups and innovative entrepreneurship. Secondary sources are processed in the theoretical part of the article. Beside the secondary sources, primary data was also processed directly linked to the entrepreneurial environment. A questionnaire survey was applied. The questionnaires were distributed to a large number of companies operating in the small and medium-sized business sector in Slovakia. The presented research results are from the second partial ethap of the research, which was conducted in 2020. 238 businesses participated in the research, which fell into the categories of innovative business and start-ups (186). In addition to the questionnaire survey, some basic research methods were also applied e.g. cognitive methods.

\section{RESULTS AND DISCUSSION}

This part of the article is oriented at the presentation of the achieved results during the partial stage of the research VEGA 1/0813/19 - "Managing the development of innovative and startup forms of businesses in international environment and verification of INMARK concept". Monitoring the results of business activities and measuring the business success were addressed by many scientists. When mapping the Slovak businesses, it is necessary to mention the 
research team Bosáková et al. (2013). Start-ups as a specific form of micro-enterprises were addressed by Slavik et al (2020).

Part of the research task conducted by us during the implementation of VEGA is to obtain information about the current innovation activity of the Slovak businesses operating in the SME sector. The partial results in form of the most important attributes of innovative start-ups will be introduced.

The research sample consisted of 186 business units operating in Slovakia. As for the categorization of these business units, micro enterprises had the highest participation ratio, followed by small businesses. The smallest representation in the survey was detected in the case of medium-sized enterprises. The results are presented in Table 1.

Table 1. Types of companies participating in the research

\begin{tabular}{|c|c|c|}
\hline & Absolute abundance & Relative abundance \\
\hline Micro enterprise & 81 & $43.55 \%$ \\
\hline Small enterprise & 68 & $36.56 \%$ \\
\hline Medium-sized enterprise & 37 & $19.89 \%$ \\
\hline $\begin{array}{l}\text { Total number of enterprises } \\
\text { participating in the research }\end{array}$ & 186 & $100 \%$ \\
\hline
\end{tabular}

Source: own research

As it was mentioned above, the smallest representation in our research, less than 1/5 was made by medium-sized companies. 37 medium-sized companies were involved in the research. A bit more than $1 / 3$ of the businesses were small enterprises, altogether 68 small businesses were involved in the research sample. The highest ratio was represented by micro enterprises, 81 businesses participated in the research. It is micro enterprises that typically represent innovation in the business sector of Slovakia, so the ratio of their representation is not surprising.

Motivation to innovate is one of the most important determinants that influence the innovative activity of the business. Therefore, we were interested in the factors that motivate the business to realize innovative activities. The obtained results are presented in Figure 1.

In a closer analysis of motivation factors, we can see that for businesses participating in the research the most important motivating factor resulting in innovation activity of the business is the differentiation from a competitor with a score of 4,4 , closely followed by smart solutions with a score of 4,1. Our results reflect the trends that those companies with innovative character and start-ups are successful on market due to their smart solutions, which are highly innovative and demanded on the market by end-users. A third most important motivation factor was marked the business idea. This factor is adequately motivating for business entities since it provides companies the possibility of self-realization i.e. implementing their business ideas. Following the first three factors which are closely linked, further factors should be mentioned that stimulate and motivate. These are based on the economic situation of the business. The fourth important motivating factor to innovate is effective utilization of production capacity. It has achieved a score of 3,0. Economic indicators are pushing companies to increase the efficiency of their activities. It was interesting that satisfying the need of the customer is one 
of the least motivating factors influencing the innovative activity of businesses. The least motivating factor was the market initiative $(2,5)$. This can be explained by the activity of competitors, further market players and the direct reaction of the company to the situation.

In the further part of the research, we were interested in the resources the company has, which are of particular importance for a business with innovative character or operate as start-ups. We found out which sources represent the most significant pillar of innovation activity. Our findings are presented in Figure 2.

Figure 1. Motivational factors resulting in innovation activity of the business

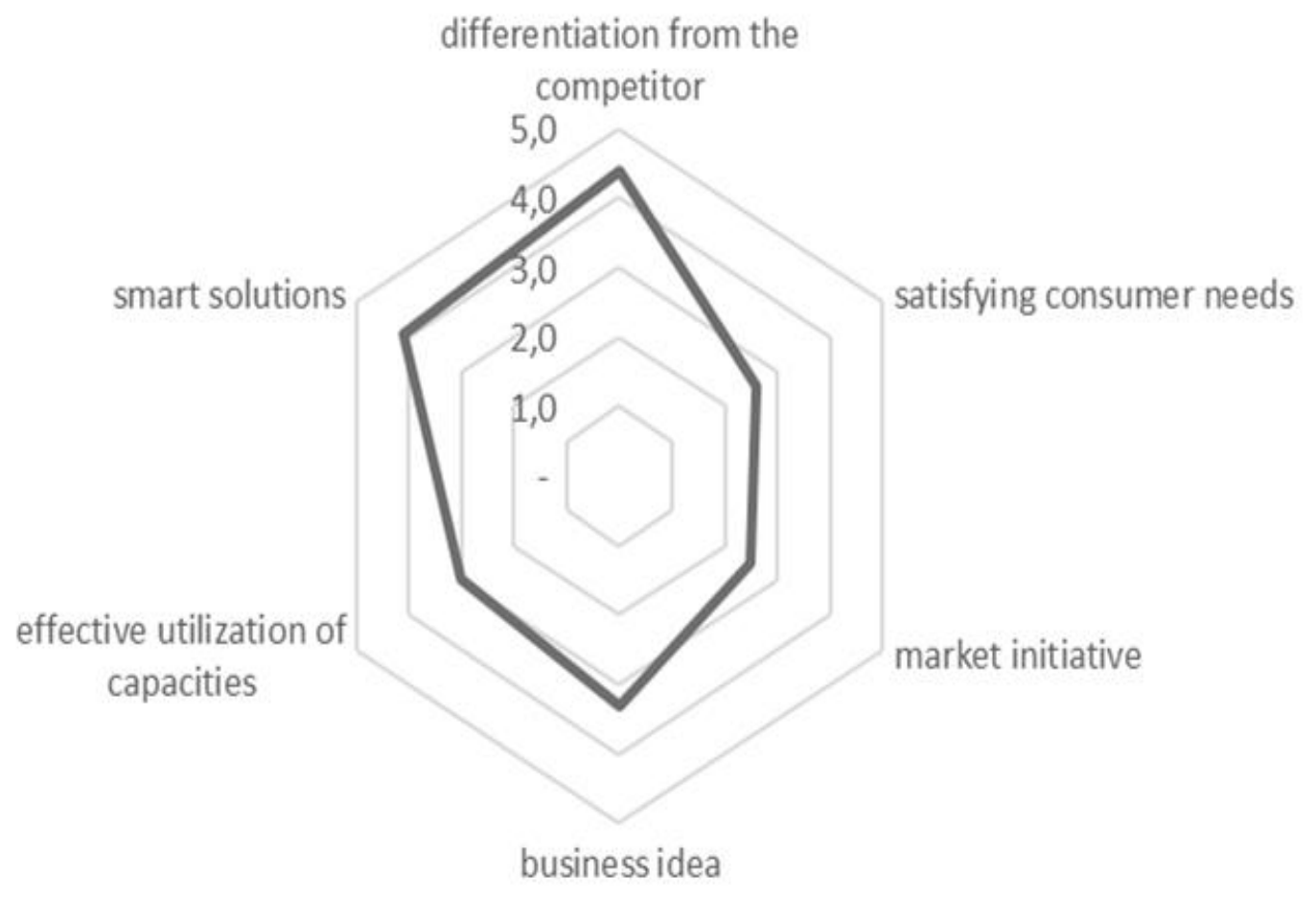

Source: own research

The most important sources of innovative activity of businesses listed by the respondents participating in this survey were the following: Human Resources, Technology, Financial Sources, Material Sources. These together form the basic pillar of innovation activity of businesses. In Figure 2 (Pareto Chart) we can monitor the results. In the case of innovative and start-up initiatives, human resources have proven to be the most important pillar of the business. Ideas are generated by individuals. In terms of innovative activities, the second most important pillar proved to be technology. It has reached the score of 4,6. Technology is a key element in the process of implementing innovations. These activities have to be backed by financial resources, which was the $3^{\text {rd }}$ most important pillar in the survey. As a last in the survey were mentioned material sources with a score of 3,7 . In addition to a good idea and cuttingedge technology, material resources are also essential to create new solutions for products and services. 
Figure 2. Sources of innovation activity of enterprises - Pareto Chart

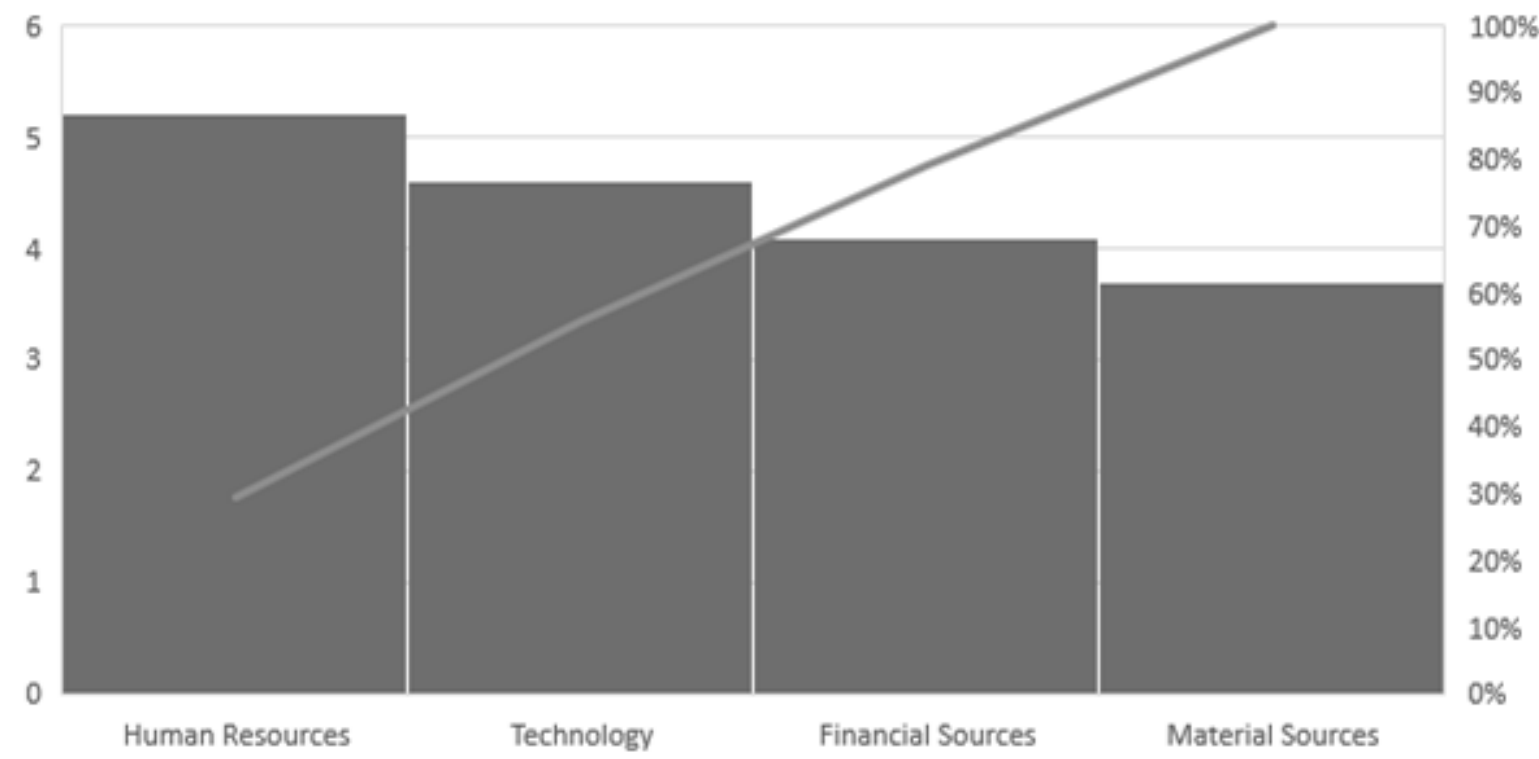

Source: own research

\section{FUTURE RESEARCH DIRECTIONS}

Research in the field of innovative small and medium-sized enterprises, micro businesses and start-ups are an extremely discussed issue since only those who are a step ahead of their competitor can remain competitive on the market. At the same time, the customer of the $21^{\text {st }}$ century has increased demands and expects that his needs will be fully met and companies will compete for his loyalty and interest by offering new, currently on the market unavailable products. The innovative ability of businesses is also reflected in offering new or improved solutions. Start-ups immediately introduce their innovative activities and put them into practice that makes our lives easier and simpler. At a time of pandemic crises caused by the SARS $\mathrm{CoV} 2$ virus, business conditions have become challenging. However, it is also an opportunity for innovative start-ups that can quickly respond to market circumstances to launch new solutions for everyday life. Economies in the transformation process and economies that operate on social-market principles, start-ups have a challenging opportunity, inspiration can gain from the example of successful enterprises of developed market economies. The future of research in the field of innovative and start-up businesses will focus on their adaptability, flexibility and financial ability or quickly respond to benefit from market opportunities.

\section{CONCLUSION}

Start-up businesses as a less developed form of entrepreneurship in Slovakia have huge perspectives. These perspectives are also supported by current trends the businesses face (increased economic competition, demand for innovative products, globalization, etc.). Startup is a type of business enterprise entering the market. The success of this business is mainly conditioned by the business model based on a clever idea and launching products required by the market. These businesses are small in size, but highly efficient and flexible in terms of new solutions arising interest. These are small enterprises that differ significantly in their structure and business concept. In this paper, we set the goal to present some of the significant partial results of our research and set a partial objective to introduce the activity of innovative start- 
ups. On the example of primary research of Slovak enterprises, we presented partial results obtained on a sample of almost two hundred enterprises. Human resources, new ideas and smart solutions are key factors, which determine not only the activity of these enterprises but to a significant extent also their business success. The strongest motivation factor turned out to be the differentiation from competitors on the market. Human resources and technology proved to be the most important pillars of the innovative enterprise. We assume that due to the national and international market trends, the share of innovative start-up companies is expected to increase.

\section{ACKNOWLEDGMENT}

This research was supported by the Ministry of Education, Science, Research and Sport of the Slovak Republic. [grant number VEGA 1/0813/19 Managing the development of innovative and start-up forms of businesses in international environment and verification of INMARK concept].

\section{REFERENCES}

Agarwal, M., Agarwal, A., Agarwal, Y., Agarwal, S. 2018. Enterprising entrepreneurship \& start-ups: Models for growth and financing of micro, small \& medium enterprises (MSMEs) in times of recession. Finance India 32(4), pp. 1125-1208

Amorós, J.E., Cristi, O., Naudé, W. 2020. Entrepreneurship and subjective well-being: Does the motivation to start-up a firm matter? Journal of Business Research (Article in Press) https://doi.org/10.1016/j.jbusres.2020.11.044

Bednar, R., Tariskova, N., Zagorsek, B. 2018. Startup Revenue Model Failures. Montenegrin Journal of Economics 14 (4), 141-157 https://doi.org/10.14254/1800-5845/2018.14-4.10

Bosáková, L., Kubák, M., Andrejkovič, M., Hajduová, Z. 2013. Doing business abroad: utility function model for country selection in preliminary screening phase. Central European Journal of Operations Research, 23 (1), 53-68

Chang, Y.S., Kim, J.H., Kim, Y.S. 2020. Convergence analysis of the entrepreneurship startup barriers. International Journal of Management and Enterprise Development 19(1), pp. 21-41. https://doi.org/10.1504/IJMED.2020.104172

Estay, C., Durrieu, F., Akhter, M. 2013. Entrepreneurship: From motivation to start-up. Journal of International Entrepreneurship 11(3), pp. 243-267. https://doi.org/10.1007/s10843013-0109-X

Millán, A., Millán, J.M., Román, C. 2016. The role of start-up incentives on entrepreneurship dynamics in a post-crisis era: Evidence from European countries. CESifo DICE Report 14(3), pp. 29-35

Milosovicova, P., Trel'ova, S. 2018. A New Type of Business in Slovakia. Innovation management and education excellence through Vision 2020, Vols I -XI, 31st International-Business-Information-Management-Association Conference, 3092-3098

Passaro, R., Quinto, I., Thomas, A. 2020. Supporting entrepreneurship policy: An overview of Italian start-up competitions. International Journal of Entrepreneurship and Innovation Management 24(1), pp. 1-30. https://doi.org/10.1504/IJEIM.2020.105274

Pitekova, J., Vrablikova, M. 2019. Benchmarking of Slovak regions in terms of start-up implementation indicators and creative potential indicators. Marketing and management of innovations, 4, 50-68. https://doi.org/10.21272/mmi.2019.4-05

Slavik, S., Srovnalikova, P., Navickas, V., Girchenko, T. 2020. Human dimension of start-up. Financial and credit activity-problems of theory and practice, 3 (34), 392-401 
Vnoučková, L. 2018. Criteria of innovativeness and creativity in start-ups and innovative entrepreneurship. Quality Innovation Prosperity 22(1), pp. 27-43. https://doi.org/10.12776/QIP.V22I1.1040 